\title{
Epidemiologic Study of Risk Factors for Hepatitis C Virus Transmission in Lorestan Province (2011-14)
}

\author{
Mohamad Reza Nazer (MD) \\ Department of Infectious Diseases, \\ Hepatitis Research Center, \\ Lorestan University of Medical \\ Sciences, Khorramabad, Iran
}

\section{Zia Obeidavi (MD)}

Student Research Committee, Lorestan University of Medical Sciences, Khorramabad, Iran

Behrouz Beiranvand (MSc) Hepatitis Research Center, Lorestan University of Medical Sciences, Khorramabad, Iran

Mahshid Garmsiri (MD)

Student Research Committee, Lorestan University of Medical Sciences, Khorramabad, Iran

Corresponding author: $\mathrm{Zia}$ Obeidavi

Email: ziaobd@gmail.com

Tel: +986633223004

Address: Lorestan University of Medical Sciences, Khorramabad, Iran

Received : 10 Aug 2014

Revised: 08 Oct 2014

Accepted: 20 Oct 2014

\section{ABSTRACT}

Background and Objective: This study was conducted to evaluate epidemiology of risk factors for hepatitis C virus (HCV) transmission, and determine the association of its genotypes with viral load and response to treatment in patients referred to the Infectious Disease Clinic of Khorramabad.

Methods: The study included patients infected with hepatitis C referred to the Infectious Disease Clinic of Khorramabad during 2011-14. Those who met the inclusion criteria were referred to counseling centers for risky behaviors. After collecting demographic and epidemiologic data on the modes of transmission, blood samples were collected for more accurate testing. The erum of patients with hepatitis C was evaluated in terms of HCV genotype and viral load using PCR.

Results: Among 120 patients studied, 102 (85\%) were male and 18 (15\%) were female. The most prevalent genotypes were 3a (63.0\%), la (25\%), la/lb (5.2\%) and 2 (1.7\%). Intravenous drug abuse was the main route of transmission of hepatitis $C$ in the study. The genotypes 3a and la had a clear correlation with intravenous drug abuse and history of blood transfusion $(\mathrm{P}<0.05)$. It was also found that the patients with genotype 3a show a better initial response to treatment with interferon.

Conclusion: The study shows that intravenous drug abuse is the main route of transmission, which highlights the need for intervention and education in this group of patients to prevent disease transmission.

Keywords: Hepatitis C, Genotype, Intravenous Drug Abuse, HIV, Interferon 


\section{INTRODUCTION}

Nowadays, infectious disease caused by hepatitis $\mathrm{C}$ virus (HCV) is a major public health problem worldwide and a main cause of chronic liver disease (1). Some studies show that about three percent of the world's population (170 million people) is infected with hepatitis C. Moreover, it is currently the most common cause of advanced hepatic malignancy $(1,2)$. The prevalence of $\mathrm{HCV}$ infection in Iran is less than one percent of the normal population (3). This indicates the lower incidence of the disease compared to neighboring countries such as Yemen (1.1\%), Saudi Arabia (8.1\% in young population) and Pakistan (4\% in blood donors) (4). HCV genome contains a positive-sense, singlestranded, $9.6 \mathrm{~kb}$ long RNA molecule (5). Various HCV strains have been isolated from different regions of the world that differ in their nucleotide sequences (6). Based on heterogeneity (diversity) of the isolates' nucleotide sequences, HCVs are classified into different genotypes and subtypes (7). In addition to clinical and epidemiological importance, HCV genotyping has a prognostic value that can be used to help determine the progressive course of the disease (8). For instance, since peginterferon + ribavirin (standard therapy) and sustained viral response depend on the genotype, the genotypes 2 and 3 respond better to treatment $(6,9,10)$. Currently, intravenous drug abuse is the main route of transmission in developing countries. Sexual transmission of $\mathrm{HCV}$ is also possible, but uncommon. Other modes of transmission include frequent contact with infected blood among healthcare personnel and perinatal transmission from mother to infant. Transmission via tattooing, cupping and sacrificing rituals is also possible, but extremely rare (11). Previous studies have been on the epidemiology of $\mathrm{HCV}$ transmission risk factors, distribution of different genotypes based on variables such as gender, age and viral load, and response to therapy. Contradictory results in different countries based on different geographical regions and ethnicities indicate the need for such studies in other countries such as Iran. Therefore, we aimed to perform an epidemiologic study of risk factors for hepatitis $\mathrm{C}$ transmission, and evaluate the relationship between genotypes and viral load and response to therapy in patients admitted to the Infectious Disease Clinic in city of Khoramabad, Iran.

\section{MATERIAL AND METHODS}

This cross-sectional study was performed on all patients with $\mathrm{HCV}$ referred to the Infectious Disease Clinic in Khoramabad during 2011-14. All participants were informed about the research project, and written consent was obtained from all of them. A trained physician interviewed all patients, and clinical information and history were collected via relevant information forms.

Diagnosis of HCV-positive patients in the ELISA method was confirmed by western blotting. These patients were referred to the counseling centers for risky behaviors in the city. Then, demographic and epidemiological data such as age, gender and possible route of transmission were collected from each patient. They were referred to pathobiology laboratories for further laboratory testing. Polymerase chain reaction (PCR) was used to determine the genotype and viral load. For this purpose, $5 \mathrm{ml}$ of blood was taken from each one and mixed with two drops of $7.5 \%$ EDTA solution. The mixture was centrifuged and the plasma was transferred to $1.5 \mathrm{ml}$ microtube. Then, viral RNA was extracted using high pure viral nucleic acid kit (Roche, Germany) according to the manufacturer's instructions. The HCV Real Time PCR kit (Rotor Gene Q) was used to determine the viral load. For genotyping, NS5B and 5UTR viral regions were amplified by RT-PCR and prepared for sequencing. The genotyping results were collected in form of codes. ELISA method was used to evaluate coinfection with HIV among the subjects. All patients received treatment

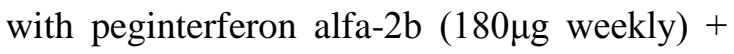
$800 \mathrm{mg}$ of ribavirin for genotypes 2 and 3. However, the dosage ranged between 800$1200 \mathrm{mg}$ per day for other genotypes based on weight of subjects. The treatment continued for six and three months for patients with genotypes 2 and 3 that showed reduced viral load of more than one log and zero in the first 
month, respectively. For other genotypes $(1,4$, 5,6 ), treatment continued for one year if more than one $\log$ (after one month) or two $\log$ (after three months) viral load reduction was detected. For other cases that were considered as resistant or non-responsive, treatment with peginterferon + ribavirin was discontinued and another treatment method with addition of boceprevir was considered. Distribution of genotype frequencies was compared by chisquare test and the relationship between variables was evaluated by Fisher's exact test. The obtained results were analyzed using SPSS software at significance level of less than 0.05 .

\section{RESULTS}

Of $120,102(85 \%)$ were male and 18 $(15 \%)$ were female. The average age was $10.29 \pm 36.54$ (range of 18-70 years). The predominant genotypes were $3 \mathrm{a}(63.8 \%)$ and 1a $(25 \%)$, followed by $1 \mathrm{a} / 1 \mathrm{~b}(5.2 \%)$ and $2 \mathrm{a}$ (1.7\%). Moreover, the genotype of five samples $(4.3 \%)$ were not typeable. Evaluation of frequency distribution of $\mathrm{HCV}$ genotypes based on age (Table 1) showed that the genotype 3a was dominant in all age groups. The prevalence of this genotype in the patients under 25 years, 25-40 years, 40-55 years and older than 55 years was $50 \%, 65.75 \%, 66.67 \%$ and $77.78 \%$, respectively. Moreover, the highest frequency of genotype 1a $(68.96 \%)$ and $3 \mathrm{a}(61.54 \%)$ was observed in the ones aged 25-40 years. The highest frequency of genotype $2 \mathrm{a}(100 \%)$ was observed in under 25 years. However, there was no statistically significant association between genotype and age groups $(\mathrm{P}=0.11)$. Evaluation of frequency distribution of HCV genotypes for each gender in the study population (Table 2) showed that the highest frequency of $\mathrm{HCV}$ genotype in males (59.4\%) and females (94.7\%) was related to the genotype $3 \mathrm{a}$. There was no significant relationship between genotype and gender $(\mathrm{P}=0.42)$. In this study, 98 patients $(81.67 \%)$ were married and only two couples were both infected. Coinfection with HIV was found in 22 patients (18.33\%) who also had history of intravenous drug abuse. No statistically significant association was found between coinfection with HIV and gender, age and viral load. The patients had history of intravenous drug abuse (48.33\%), tattooing (18.33\%), dental procedures $(25.38 \%)$ and blood transfusion [20.83\% (15\% for surgery and $5.83 \%$ for haemoglobinopathy)]. In addition, $30 \%$ of patients had a history of unsafe sex. In this study, the genotypes $3 \mathrm{a}$ and 1a were the predominant genotypes among intravenous drug abusers and the patients with the history of blood transfusion $(\mathrm{P}<0.05)$. No significant relationship was found between genotypes and other risk factors. The results also showed that the people with genotype $3 \mathrm{a}$ show better initial response to treatment with interferon (IFN). The results also showed that the participants with genotype 1a had higher viral load compared to other genotypes (Table 3). Given the non-normality of data, nonparametric tests were used to compare genotypes' viral load. The Kruskal-Wallis test showed a significant difference in the viral load of genotypes $(\mathrm{P}=0.007)$. The MannWhitney test showed that the viral load of genotype 1a was significantly higher than genotypes $3 \mathrm{a}(\mathrm{P}=0.043)$ and $1 \mathrm{a} / 1 \mathrm{~b}(\mathrm{P}=0.048)$. Moreover, the viral load of genotype 2 was significantly lower than other genotypes.

Table 1- Frequency distribution of HCV genotypes based on age of patients with hepatitis C

\begin{tabular}{|c|c|c|c|c|c|c|}
\hline \multirow[t]{3}{*}{ Genotype } & \multicolumn{4}{|c|}{ Age group } & \multirow{3}{*}{$\begin{array}{c}\text { Total } \\
\text { Number }(\%)\end{array}$} & \multirow[t]{3}{*}{ P-Value } \\
\hline & $<25$ & $25-40$ & $40-55$ & $\geq 55$ & & \\
\hline & Number $(\%)$ & Number $(\%)$ & Number (\%) & Number (\%) & & \\
\hline 1a & $4(13.79)$ & $20(68.96)$ & $3(10.34)$ & $2(6.89)$ & $29(100)$ & $P=0.11$ \\
\hline $1 a, 1 b$ & $\mathbf{0}(\mathbf{0})$ & $1(16.67)$ & $5(83.33)$ & $0(0)$ & $6(100)$ & \\
\hline $\mathbf{2 a}$ & $2(100)$ & $\mathbf{0}(\mathbf{0})$ & $\mathbf{0}(\mathbf{0})$ & $\mathbf{0}(\mathbf{0})$ & $2(100)$ & \\
\hline $\mathbf{3 a}$ & 7 (8.97) & $48(61.54)$ & $16(20.51)$ & 7 (8.97) & $78(100)$ & \\
\hline Non-typeable & $1(20)$ & $4(80)$ & $\mathbf{0}(\mathbf{0})$ & $\mathbf{0}(\mathbf{0})$ & $5(100)$ & \\
\hline Total & 14 (11.67) & $73(60.83)$ & $24(20)$ & $9(7.5)$ & $120(100)$ & \\
\hline
\end{tabular}


Table 2- Frequency distribution of HCV genotypes based on gender of patients with hepatitis $\mathrm{C}$

\begin{tabular}{|c|c|c|c|c|c|c|c|}
\hline Gender & \multicolumn{5}{|c|}{ Genotype } & & P-Value \\
\hline $\begin{array}{c}\text { Male } \\
\text { Female } \\
\text { Total }\end{array}$ & $\begin{array}{c}1 \mathrm{a} \\
\text { Number }(\%) \\
28(96.55) \\
1(3.45) \\
29(100)\end{array}$ & $\begin{array}{c}1 \mathbf{a}, 1 \mathbf{b} \\
\text { Number }(\%) \\
6(100) \\
0(0) \\
6(100)\end{array}$ & $\begin{array}{c}2 \mathrm{a} \\
\text { Number }(\%) \\
2(\mathbf{1 0 0}) \\
0(0) \\
2(100)\end{array}$ & $\begin{array}{c}\text { 3a } \\
\text { Number }(\%) \\
57(77.02) \\
17(22.98) \\
74(100)\end{array}$ & $\begin{array}{c}\text { Non-typeable } \\
\text { Number }(\%) \\
5(100) \\
0(0) \\
5(100)\end{array}$ & $\begin{array}{c}\text { Number }(\%) \\
102(85) \\
18(15) \\
120(100)\end{array}$ & $P=0.42$ \\
\hline \multicolumn{8}{|c|}{ Table 3-Relationship between genotype and viral load in patients with hepatitis } \\
\hline \multirow{2}{*}{\multicolumn{2}{|c|}{ Genotype }} & \multicolumn{6}{|c|}{ Viral load } \\
\hline & & $\begin{array}{c}<100000 \\
\text { Number }(\%)\end{array}$ & & $\begin{array}{c}10^{5}-10^{6} \\
\text { Number }(\%)\end{array}$ & $\begin{array}{c}10^{6}-10^{7} \\
\text { Number }(\%)\end{array}$ & & $\begin{array}{c}>10^{7} \\
\text { Number (\%) }\end{array}$ \\
\hline & & $0(\mathbf{0})$ & & $6(20.7)$ & 17 (58.6) & & $6(20.7)$ \\
\hline & & $\mathbf{0}(\mathbf{0})$ & & $2(33.3)$ & $4(66.7)$ & & $\mathbf{0}(\mathbf{0})$ \\
\hline & & $2(100)$ & & $\mathbf{0}(\mathbf{0})$ & $\mathbf{0}(\mathbf{0})$ & & $\mathbf{0}(\mathbf{0})$ \\
\hline & & 17 (21.8) & & $21(26.9)$ & $26(33.3)$ & & 14 (17.9) \\
\hline & peable & $1(20)$ & & $2(40)$ & $2(40)$ & & $\mathbf{0}(\mathbf{0})$ \\
\hline
\end{tabular}

\section{DISCUSSION}

In this study, 120 patients with hepatitis C were studied. According to the results, the number of male patients is significantly higher than that of females that could be due to higher rate of high-risk behaviors such as intravenous drug abuse in men. This is consistent with the results of other studies conducted in the European countries and the United States (12). The Genotype $3 \mathrm{a}$ was the predominant genotype in this study, which is in line with the findings of studies conducted in India, Pakistan and Nepal $(13,14)$. However, these findings are inconsistent with the results of studies in Saudi Arabia (15), Kuwait (16), France (17), North American countries (18) and South Korea (19). This difference could be due to high prevalence of intravenous drug abuse in the present study (48.33\%) because numerous molecular epidemiological studies suggest an association between genotype 3a transmission and history of intravenous drug abuse $(13,16,20)$. In other words, the variants of genotype $3 \mathrm{a}$ can be considered a global epidemic in intravenous drug abusers.

The Genotype 1a was the second most common genotype in the study, which is in agreement with the results of other studies (21, 22). For example, a study on 125 samples collected from the South, Northwestern Iran and Tehran found 1a as the most prevalent genotype $(47 \%)$. In the mentioned study, the genotype $3 \mathrm{a}$ was prevalent in intravenous drug on the relationship between genotype and serum viral load. In a study on 379 patients in Germany, the patients with genotype 3 had significantly lower viral load compared to the ones with genotype 1 (25). This is coordinated with the results of the present study that showed genotype 1a has higher viral load compared to other genotypes. A study in Spain showed that patients with genotype 3 has higher viral load, which is inconsistent with our results (26). In another study in Iran, the highest viral load was reported for genotypes $1 \mathrm{~b}, 1 \mathrm{a}$ and $3 \mathrm{a}$ (27). The present study also found that the people with genotype $3 \mathrm{a}$ show better initial response to treatment with IFN, which is partially consistent with the results of the study conducted by Bjoro et al. in Norway. In the mentioned study, patients with genotype 3a, low viral load and no cirrhosis showed better initial response to treatment with IFN (28). However, another study in Japan showed that suitable response to IFN treatment is usually observed in patients with genotype $2 \mathrm{a}$ and high viral load (29).

\section{CONCLUSION}

Drug addiction was found as the main mode of HCV transmission in this study. Therefore, preventive strategies are required with greater emphasize on this group to prevent the progression of an epidemic in this group of people. 


\section{ACKNOWLEDGMENTS}

The authors wish to acknowledge the staff of Central and Noor Pathobiology Laboratories in Khorramabad and Department of Research at Lorestan University of Medical

\section{REFERENCES}

1. Bostan N, Mahmood T. An overview about hepatitis C: a devastating virus. Crit Rev Microbiol. 2010; 36(2): 91-133. doi: 10.3109/10408410903357455.

2. Alavian SM, Adibi P, Zali MR. Hepatitis $C$ virus in Iran: Epidemiology of an emerging infection. Arch Iranian Med. 2005; 8(2): 84-90.

3. Tamaddoni A, Mohammadzadeh I, Ziaei O. Seroprevalence of HCV antibody among patients with beta-thalassemia major in Amirkola Thalassemia Center, Iran. Iran J Allergy Asthma Immunol. 2007; 6(1): 41.

4. Khattak MF, Salamat N, Bhatti FA, Qureshi TZ. Seroprevalence of hepatitis $B, C$ and HIV in blood donors in northern Pakistan. J Pak Med Assoc. 2002; 52(9): 398-402.

5. Suzuki T, Aizaki H, Murakami K, Shoji I, Wakita T. Molecular biology of hepatitis $C$ virus. J Gastroenterol. 2007; 42(6): 411-23. DOI: 10.1007/s00535-007-2030-3.

6. Freitas SZ, Dacunha RV, Martins RM, Tales SA, Ibanhes ML, Motta-Castro AR. Prevalence, genotypes and risk factors associated with hepatutus $C$ virus infection in hemodialysis patients in Campo Grande, MS, Brazil. Mem Inst oswaldo cruz. 2008; 103: 405-7.

7. Dienstag, Kurt J, Isselbacher. Chronic hepatitis in Harrison's principles of internal medicine. $16^{\text {th }}$ ed. McGraw Hill. 2005; 1844-53.

8. Perz JF, Armstrong GL, Farrington LA, Hutin YJ, Bell BP. The contributions of hepatitis $B$ virus and hepatitis $C$ virus infection to cirrhosis and primary liver cancer worldwide. J Hepatol. 2006; 45(4): 529-38.

9. Nguyen MH, Keeffe EB. Epidemiology and treatment outcomes of patients with chronic hepatitis $C$ and genotypes 4 to 9. Rev Gastroenterol Disord. 2004; 4 Suppl 1: S14-21.

10. Jimenez-Mendez R, Uribe-Salas F, Lopez-Guillen P, Cisneros-Garza L, Castaneda-Hernandez G. Distribution of HCV genotypes and HCV RNA viral load in different regions of Mexico. Ann Hepatol. 2010; 9(1): 33-39.

11. Svirtlih N, Delic D, Simonovic J, Jevtovic D, Dokic $\mathrm{L}$, Gvozdenovic E, et al. Hepatitis $C$ virus genotypes in Serbia and Montenegro: The prevalence and clinical significance. World J Gastroenterol. 2007; 13(3): 355-60.

12. Matheï C, Wollants E, Verbeeck J, Van Ranst M, Robaeys G, Van Damme P, et al. Molecular epidemiology of hepatitis $C$ among drug users, correlation with clinical parameters, sexual behavior and drug-related behavior. Eur J Clin Microbiol Infect Dis. 2005; 24(8): 514-22.
Sciences.

\section{CONFLICT OF INTEREST}

All contributing authors declare no conflicts of interest.

13. Amarapurkar D, Dhorda M, Kirpalani A, Amarapurkar A, Kankonkar S. prevalence of HCVgenotypes In Indian patients and their clinical significance. J Assoc physicians India. 2001; 49: 983-5.

14. Afridi SQ, Ali MM, Awan F, Zahid MN, Afridi IQ, Afridi SQ. Molecular epidemiology and viral load of $\mathrm{HCV}$ in different regions of Punjab, Pakistan. Virology Journal. 2014; 11:24. DOI: 10.1186/1743-422X-11-24.

15. Osoba AO, Ibrahim M, Abdelaal MA, Al-Mowallad A, Al Shareef B, Hussein BA. Hepatitis $C$ virus genotyping by polymerase chine Reaction and Enzyme immunoassay Among Saudi patients in the western province, Saudi Arabia. Ann Saudi med. 2000; 20(5-6): 394-7.

16. Pacsa AS, Al-Mufti S, Chugh TD. Genotypes of Hepatitis C Virus in Kuwait. Med Princ Pract. 2001; 10(1): 55-7.

17. Martinot-Peignoux M, Roudot-Thoraval F, Mendel I, Coste J, Izopet J, Duverlie G, et al. Hepatitis $C$ virus genotypes in France: relationship with epidemiology, pathogenicity and response to interferon therapy. The GEMHEP. J Viral Hepat. 1999; 6(6): 435-43.

18. Rosen HR, Chou S, Sasaki AW, Gretch DR. Molecular epidemiology of hepatitis $C$ infection in U.S. veteran liver transplant recipients: evidence for decreasing relative prevalence of genotype $1 B$. Am J Gastroenterol. 1999; 94: 3015-9.

19. Oh DJ, Park YM, Seo YI, Lee JS, Lee JY. Prevalence of Hepatitis $C$ Virus Infections and Distribution of Hepatitis C Virus Genotypes among Korean Blood Donors. Ann Lab Med 2012; 32: 210-215.

20. Moreno Planas JM, Fernández Ruiz M, Portero Azorin F, Boullosa Graña E, Rubio González E, Martín Garcia S, et al. Prevalence of Hepatitis $C$ Virus genotypes in a Spanish liver transplant unit. Transplant Proc. 2005; 37(3): 1486-7.

21. Assarezadegan MA, Shakerinejad Gh, Norouzirad R, Amini A. Distribution of hepatitis $C$ virus genotypes among patients with hepatitis $C$ infection in Khuzestan province. Medical Science Journal. 2008; 7:471-9. doi: $10.5812 /$ hepatmon. 14324 .

22. Hadinedoushan H, Salmanroghani H, Amirbaigy MK, Akhondi-Meybodi M. Hepatitis C Virus Genotypes and Association with Viral Load in Yazd, Central Province of Iran. Hepat Mon. 2014; 14(3): e11705.

23. Samimi-Rad K, Nategh R, Malekzadeh R. Molecular epidemiology of hepatitis $C$ virus in Iran as reflected by phylogenic analysis of the NS5B region. J Med Virol. 2004; 74(2): 246-52. 
24. Afsharian M, Raoufi R, Vaziri S, Janbakhsh AR, Mansouri F, Ghadiri K, Saiad B, Leghaei Z. HCV genotypes in patients referred to Sina hospital in Kermanshah during 2005 to 2006. Journal of infectious and tropical disease. 2007; 39: 19-23.

25. Berg T, Hopf U, Stark K, Baumgarten R, Lobeck H, Schreier E. Distribution of hepatitis $C$ virus genotypes in German patients with chronic hepatitis $C$ : correlation with clinical and virological parameters. $\mathrm{J}$ Hepatol. 1997; 26(3): 484-91.

26. Rodriguez JC, Garcia J, Moya I, Ayelo A, Vazquez $\mathrm{N}$, Sillero C, et al. Genetic variability of hepatitis $C$ virus in the health area of Elche (Spain). Correlation between core antigen and viral load. Gastroenterol Hepatol. 2003; 26(7): 407-10.
27. Garcia F, Roldan C, Hernandez-Quero J, Bernal MC, Martinez MA, Lopez MA, et al. Relationship between viral genotype and viral load in patients with chronic hepatitis C. Eur J Clin Microbiol Infect Dis. 1996; 15(11): 884-7.

28. Bjoro K, Bell H, Myrvang B, Skaug K, Raknerud N, Sandvei $\mathrm{P}$, et al. Effect of interferon-alpha induction therapy on genotype $2 b / 3 a$ and low viral load hepatitis $C$ virus infection. A randomized multicentre study. Scand $\mathrm{J}$ Gastroenterol. 2002; 37(3): 344-9.

29. Nakamura H, Ogawa H, Kuroda T, Yamamoto M, Enomoto H, Kishima Y, et al. Interferon treatment for patients with chronic hepatitis $C$ infected with high viral load of genotype 2 virus. Hepato-gastroenterology. 2002; 49(47): 1373-6. 